Meta

Journal des traducteurs

Translators' Journal

\title{
Understanding the Silent Culture of the Japanese
}

\section{Fujiko Hara}

Volume 33, numéro 1, mars 1988

Traduction et interprétation au Japon

Translation and Interpretation in Japan

URI : https://id.erudit.org/iderudit/003024ar

DOI : https://doi.org/10.7202/003024ar

Aller au sommaire du numéro

Éditeur(s)

Les Presses de l'Université de Montréal

ISSN

0026-0452 (imprimé)

1492-1421 (numérique)

Découvrir la revue

Citer cet article

Hara, F. (1988). Understanding the Silent Culture of the Japanese. Meta, 33(1),

22-24. https://doi.org/10.7202/003024ar d'utilisation que vous pouvez consulter en ligne.

https://apropos.erudit.org/fr/usagers/politique-dutilisation/ 


\title{
UNDERSTANDING THE SILENT CULTURE OF THE JAPANESE
}

FuJiko Hara

Tokyo, Japan

\begin{abstract}
"What does 'hai' mean ?" asked an expatriate on his first visit to Japan, "One hears it all the time !" "Hai" is perhaps the most versatile and frequently used word in the Japanese language. Ask a bellboy for a taxi - "Hai". Call room service — "Hai, hai !" Talk to your local business partner on the telephone and you will hear a string of "Hai ... Hai"s. $\mathrm{He}$ is simply reassuring you that he is still there and listening.

The term means "yes". But it can also mean "no". In the latter case, the clue generally is a lackluster "hai" followed by a muddled, lengthy and inappropriate explanation suggesting "no". This seeming contradiction and lack of logic is offensive and a mark of insincerity to a Western mind. Understand the "yes" portion of the sentence as a demonstration of good will and the negative part as the substance of the message. Granted that every language has its ambiguities, but the problem is amplified in Japanese by a cultural abhorrence of dissensions. As a tool for transcultural communication the Japanese language presents problems at two levels : linguistic and sociocultural.
\end{abstract}

\section{LINGUISTIC PROBLEMS}

Difficulties arise with the sentence structure. As in German, the verb in Japanese sentences comes right at the end, and the subject is often concealed in a thicket of qualifying and modifying clauses that may be a page long. This poses a severe handicap for simultaneous interpreters who must take a stab in the dark to insert a subject and a verb before they can go on. The risk of perhaps choosing the wrong verb and even the wrong subject is doubly great when information as to whether the sentence is affirmative or negative comes only as a revelation at the end.

The following "sentence" has already been "translated" - but what does it mean ? It still has to be interpreted. To try somehow to render a muddle like this faithfully, coherently, simultaneously and largely backwards into English is the interpreter's job :

Before many more years would pass, the cry "to the Bastille" and an unprecedented social transformation would convulse the whole of France ... on the eve of the revolution ... the prose translation of Dante's Divine Comedy on which he has been working for some time ... his abundant knowledge of the classics and the eloquence of his oratory had commanded the attention of the literary world of the age of enlightment in eighteenth century France where the cultural pillar Voltaire had just died and the influential magazine Mercure de France which published literary criticisms was passing into the hands of Antoine de Rivarol (1753-1801) ... (who) has won the first prize in the Berlin Academy contest with his essay "Discours sur l'universalité de la langue française" ... (but for his) disappointment with the aristocracy and his championing of the popular monarchy ... protesting the human rights declaration and (working on what was) an original undertaking for his time ... a dictionary of the French language ... an exile in Germany where he met his death, (he) would have remained as an episodic figure who would gradually have faded in people's memories. 


\section{SAME SOUND, DIFFERENT MEANING}

Then there is a problem, as in other languages, with words having similar sounds but different meanings. When the ancient Japanese adopted the Chinese script they did so without at the same time adopting the vocal tone discriminators. As a consequence the language abounds in sounds that are similar and words can only be correctly discriminated in writing. This is why you often see a Japanese trying to decide the meaning of a word by writing in mid-air or on the palm of his hand. The sense of words containing confusing sounds can often be determined from the context in which they are used but many escape contextual scrutiny. Some examples : ai kan, written 哀感, means "sad feeling", and 哀数 , either "sadness" or "joy". Au meaning "to meet" has various fine nuances depending on the Chinese character used. Written 会j, it means to meet a certain person; 通广, to meet unexpectedly (for example on a street); 合j to fit (clothes), to show the right time (watch or clock), to be correct (calculation); 遭う, to encounter undesirable things (e.g. earthquake, rain); and 逢j, a tryst. Namanurui means "lukewarm" when written 生温い ("raw-warm"), but "lax" when 生温い written 生㖃い ("raw-loose") as in "lax law enforcement" or in 生瑶い an imprecise answer. Narau, "to learn", written, 習う means to learn by a repetitive process as in "learning to write". But written 做う, it means "to copy" (what already exists) and to learn from example. There is a significant use of the latter characters when talking of learning from Europe and America.

\section{SOCIOCULTURAL PROBLEMS}

Even greater obstacles to interpreting to or from Japanese are the cultural idiosyncracies which provide the basis for communication in that language. A Japanese sees another Japanese as an extension like himself of homogeneous national identity, rather than as a separate person with an independent mind. He takes it for granted that he understands his fellow Japanese and is naively confident that he is also understood. Sharing a single language reinforces this belief. In such a relationship there is little incentive for debate or explanation. Between people who enjoy such uncontroversial relationships little needs to be said. And so, gradually, the silent culture has developed.

\section{INTERPRETING THE UNSPOKEN WORD}

I had a most uncomfortable feeling when watching the English version, entitled "The Combined Fleet", of a Japanese film called "Tora Tora Tora". There was a scene in which two Japanese admirals had to make a critical decision. "Are you sure that this is His Majesty's will ?" inquired one. "Yes", replied the other. The two had not discussed nor would they discuss what the imperial will was. Each was expected to understand what the other was thinking by virtue of the certainty that they shared the same objective. Clannish and proud of their cultural uniqueness, the Japanese can never admit to not quite understanding each other. Contemporary life abounds with such scenes.

\section{JAPANESE IS ESSENTIALLY A WRITTEN, NOT ORAL, LANGUAGE}

In addition to the general negative attitude towards any need to explain oneself clearly, speech itself is a relatively new skill encouraged only since the beginning of the Meiji era in 1868. Even the enlightened nationbuilders of that time had a difficult time communicating since the written word had traditionally been the medium of learning and acquiring knowledge. Adjusting to the novel languages first of China and later of the West meant isolating oneself from others to wrestle with the script, not conversing. The biblical "in the beginning was the word" is an unfamiliar concept. 


\section{INTERPRETING IS DETECTIVE WORK}

Understanding the Japanese often requires detective work. Sometimes it is like being led into a labyrinthine stream-of-consciousness. At other times the amount of missing information suggests the hand of master censorship. In a country in which decisions are made by consensus to avoid embarrassing the parties involved, controversial words and argument are left out or exchanged for ones which are easy to live with. A final smooth and unoffending text may be far from the original and true intention. A rather conspicuous signboard perched on a Tokyo rooftop reads : "Come back, Northern Territory !" The Northern Territory is obviously not going to come back on its own two legs. What is missing is the subject "we the Japanese people", the verb "demand", and the courage to say what we really mean : that the Soviet Union should return our Northern Territory which we believe it unlawfully occupies.

\section{ECONOMICALLY CLASSLESS, CULTURALLY HIERARCHICAL}

While Japan is a classless society in terms of the economic stations of life, there is a pervasive cultural and social hierarchy. This is manifested in all the idioms of the silent culture and constantly pervades the spoken language. Intricate social mannerisms of the French " $t u$ " and "vous" type still exist and require sensitive handling. To put it simply, a "superior" will be ruffled if addressed as if he were an "inferior". The reverse will embarrass a person of inferior rank. Excessive formality will be taken as deliberately creating "psychological distance", and lack of due form is perceived as a breach of respect and courtesy. Wrong use of hierarchical language can torpedo business talks, offend judges in court or alienate a well-meaning audience. Linguistic etiquette, required of all classes, is a sine qua non of correct human relations.

\section{INTERPRETER TRAINING}

All these pointers suggest important themes for training interpreters. They must be trained to comprehend the unspoken thought and to keep their heads up in the swamp of stream-of-consciousness. A young Japanese returning to Japan after living abroad is not necessarily the best candidate. Fluency in a foreign language is not a substitute for ignorance or inexperience in handling Japanese cultural peculiarities and social etiquette.

\section{A TIP FOR PEOPLE WHO USE INTERPRETERS}

Foreign governments rarely brief interpreters before assignment when they are Japanese nationals, for fear, I suppose, of a possible security leak. Your interpreter is a member of the team, and an important one, so treat her (or him) well. This has a strong bearing on the success of a negotiation or communication.

Remember too that an interpreter is a tool from which only the experienced user will get the best results. An interpreter is like a filter whose efficiency is a function of the size of its mesh (i.e. the interpreter's professional experience and knowledge of the subject) and the nature and quality of the material filtered. A fine mesh works best for fine material. Really, a good interpreter is more like a complete coffee maker, which simultaneously grinds, sifts and transforms the rich but unpalatable foreign grounds and produces from their essence the perfect café filtre. 